\title{
Negócios sagrados: notas sobre o Círio de Nazaré em Belém-Pará
}

\section{Sacred Business: notes about "Círio de Nazaré" in Belém-Pará}

Vanda Pantoja - Doutora em Antropologia Social pela UFPA (2011); professora adjunta do Centro de Ciências Sociais, Saúde e Tecnologia da Universidade Federal do Maranhão. E-mail: vanpantoja@gmail.com

\section{Resumo}

Este texto reúne dados de campo coletados entre os anos de 2003 e 2011. Tem como objetivo pontuar algumas mudanças que ocorrem nas gerências das festas de santos católicos na Amazônia Brasileira, particularmente no culto a Nossa Senhora de Nazaré, na celebração do Círio de Nazaré, na cidade de Belém (PA). Analisamos essas mudanças como sintomas do atual contexto de pluralismo religioso em que as instituições religiosas são colocadas em situação de Mercado Religioso, tendo, por isso, que travar intensa disputa com suas concorrentes - as outras formas religiosas - por fiéis e por espaço de atuação.

\begin{abstract}
In this paper we can find some field research data collected by the author during 2003 and 2011. It aims to point out some changes that occur on the management of the catholic feast saints in the Brazilian Amazon, particularly in the cult of Our Lady Nazareth during the Cirio de Nazaré celebration located in Belém, State of Pará. We analyze these changing as a symptom of the religious pluralism in the current context where religious institutions are placed in a Religious Market sphere, and, so they have to wage a intense battle against the competitors - others religious manifestations - for conquering faithful people and perfomance space.
\end{abstract}

\section{Palavras-chave}

Círio de Nazaré. Mercado religioso. Bens simbólicos.

\section{Keywords}

Círio de Nazaré. Religious Market. Simbolic wealth. 


\section{INTRODUÇÃO}

As celebrações aos santos são muito comuns em todo o Brasil e podese dizer que são expressivas da religiosidade brasileira. Em Belém, capital do estado do Pará, a devoção a Nossa Senhora de Nazaré, conhecida como Círio de Nazaré, ou simplesmente Círio, acontece há 311 anos como devoção e 218 anos como celebração formal ${ }^{1}$. É uma das festas católicas mais importantes do Brasil em termos de mobilização de pessoas. É o evento mais importante do calendário católico na cidade de Belém, e todos os anos, num período de cerca de vinte dias, mobiliza mais de dois milhões de fiéis em procissão pelas ruas da cidade. Sua preparação envolve um aparato de organização digno de um grande espetáculo².

$\mathrm{O}$ apelo que as festas de santos e santas católicos têm para com os devotos pode ser entendido pela importância que o objeto santo tem no repertório de crenças do catolicismo. O devoto mantém uma relação de proximidade, respeito e devoção pelo santo, que somente pode ser entendida no contexto das festas. Nas pesquisas feitas por Maués (1995), a imagem do santo aparece para seus devotos como fator de distinção entre os universos católicos e evangélicos (protestante), sendo, por isso, um forte componente de identidade católica. Este autor pontua também que os devotos não "confundem" os santos com suas imagens ou representações materiais (MAUÉS, 1995, p. 177). Em recente pesquisa pela região do Marajó, estado do Pará, observou-se a natureza "intimista" presente na relação entre devoto e santo de devoção - um misto de "temor/respeito e amor/ devoção (BARROS; PANTOJA, 2010).

Paralelo à importância do Círio como celebração católica, devido ser um momento em que a Igreja Católica e católicos se aproximam, tendo em vista o grande apreço que os devotos têm para com a santa, a capital do Pará se apresenta também como importante lócus de atuação dos evangélicos. Belém seria a segunda capital do Brasil em importância para o pentecostalismo e também ocuparia a segunda posição entre as capitais que apresentaram maior

1 Fazemos essa distinção porque de acordo com os relatos sobre a origem da devoção na cidade de Belém, a mesma teria iniciado no ano de 1700, quando do achado de uma imagem de santa por um nativo, mas a celebração conhecida como Círio somente fora organizada no ano de 1793, a partir da intervenção da Igreja Católica e do Estado.

2 Em termos de representatividade, sem dúvida, a celebração do Círio ocupa um lugar especial, pois é a única celebração religiosa registrada pelo Instituto do Patrimônio Histórico e Artístico Nacional como Patrimônio Cultural de Naturez̧a Imaterial, no Livro das Celebrações, dentro do plano de valorização e salvaguarda de manifestações artístico-culturais de grande relevância para a identidade local, nacional e regional. Este processo foi realizado depois de exaustivo levantamento documental sobre o bem e posterior avaliação por um corpo de especialistas do Departamento de Patrimônio Imaterial do Ministério da Cultura, no ano de 2004.

Novos Cadernos NAEA •v. 15 n. $2 \cdot$ p. 261-278 • dez. 2012 
variabilidade no número de evangélicos, de acordo com os censos de 1991 e 2000, sendo essa variabilidade, no caso de Belém, superior a 8\% (JACOB et al., 2006). Por outro lado, os católico que eram $82,4 \%$ no censo de 1991 , passaram a ser 71,4\% em 2000 (IBGE, 2011).

Tendo em vista essa realidade, a Igreja Católica em Belém necessita se movimentar em campo e (re) criar formas que tragam de volta e/ou mantenham os fiéis em seu território, daí a importância de celebrações como o Círio, devido a sua capacidade de mobilizar pessoas em torno da devoção a Nossa Senhora de Nazaré e, consequentemente, da Igreja Católica.

As festas de santo em geral, e o Círio de Nazaré, em particular, são entendidos pela Igreja Católica local como momentos privilegiados de aproximação entre Igreja e povo, pelo fato de condensarem anseios daquilo que entendemos como catolicismo eclesial, com práticas do catolicismo popular. Constitui, por isso, importante instrumento de evangelização, na visão da instituição. São importantes também por guardarem grande apelo popular devido à presença da imagem do santo, que tem uma grande importância para o católico. No entanto, a Igreja Católica entende que para que as festas de santo sejam de fato eficientes canais de evangelização, é necessário que estejam sob tutela da Igreja. Isso implica dizer que há atualmente um reforço no desejo de controle e na disciplina sobre essas festas por parte da Igreja, o que acarreta mais combustível nos conflitos desde sempre existentes entre clero e leigos, sobre qual deve ser o modelo dessas festas ${ }^{3}$.

Sobretudo no campo das gerências dessas celebrações, sejam estas de pequeno porte, como as centenas de festejos a santos e santas na região do Marajó, no estado no Pará; ou de grande porte, como o caso do Círio de Nazaré, em Belém, percebemos a movimentação da Igreja Católica no sentido de procurar formas de manter-se em situação confortável no mercado de bens simbólicos, tendo em vista o contexto de pluralismo e de disputa por campo de atuação ocasionada pela presença de outras formas religiosas, a exemplo dos pentecostais.

Essa movimentação da Igreja precisa ser estratégica, no sentido que é uma ação que visa obter um fim. Pelo caráter novo de algumas das situações colocadas, muitos desafios são impostos à instituição.

a) A ideia de disciplina sobre as festas precisa parecer uma decisão partilhada entre clero e comunidade;

b) A dificuldade em conciliar as noções diversas sobre o catolicismo, tanto no interior das Diretorias ou Comissões desses festejos, como fora, no trato com os leigos;

Para maiores detalhes sobre tais conflitos conferir Maués (1995). 
c) A necessidade de conciliar as diferentes representações sobre as celebrações católicas. O povo que as vê não apenas como manifestação religiosa, mas como canal de expressão de sua religiosidade; o mercado que as descobriu e se fez descobrir por essas como um grande filão, um bem com grande potencial para o comércio; a Igreja que as vê como instrumento de evangelização e, consequentemente, como canal de reprodução de sua ação, desejada como hegemônica na sociedade.

d) $\mathrm{O}$ cuidado que as instituições religiosas precisam ter ao negociar no mercado secular um bem de natureza simbólica.

Algumas dessas questões aparecem como novas para a gerência das festas católicas, não pelo fato de serem novidades, mas por exigirem uma nova postura dos gestores religiosos.

De forma geral, localizo três grandes ações da Igreja Católica na capital paraense, que têm como objetivo o desejo de (re) afirmar sua condição confortável no mercado de bens simbólicos: a feitura de um censo na cidade de Belém para "conhecer" seu rebanho, o desmembramento da Arquidiocese de Belém para criação de uma nova diocese - a de Castanhal, e a potencialização da festa religiosa católica mais importante da região e uma das mais importantes do Brasil - o Círio de Nossa Senhora de Nazaré.

\section{CENSO CATÓLICO: PARA CONHECER SEU REBANHO...}

Em junho de 2005, a Arquidiocese de Belém deu início a uma série de pesquisas que tinham como finalidade definir "O perfil sociorreligioso dos católicos". O Censo Paroquial foi realizado através da aplicação de questionários com questões que tratavam, dentre outros assuntos, sobre a frequência dos católicos às missas dominicais, a devoção aos santos e a atuação no convívio paroquial. O trabalho foi realizado por agentes voluntários nas 53 paróquias da Arquidiocese de Belém e cada paróquia recebeu uma média de seis mil questionários. Dos cerca de 300 mil questionários, apenas 150 mil foram respondidos. Um dos objetivos da arquidiocese era que o resultado da pesquisa os ajudasse na elaboração do Plano Pastoral para o ano de 2006.

O questionário continha questões que tratavam sobre grau de escolaridade, profissão e atuação dos fiéis nas igrejas. Havia espaço também para que o fiel tratasse sobre sua situação "sociorreligiosa", condições de moradia, situação salarial, prática espiritual e participação na paróquia. Foram elaboradas 24 questões objetivas e subjetivas, divididas em três blocos. Havia espaço especial 
para os fiéis sugerirem algumas ações para a melhoria da vida paroquial na Região Metropolitana de Belém.

Segundo o coordenador do censo, a intenção era descobrir qual a realidade de vida do povo católico, para então se ter ciência das razões que levam as pessoas a se afastarem da Igreja; desejava-se saber também sobre as razões que fazem com que algumas pessoas mantenham uma participação ativa na instituição e outras não. Os primeiros resultados do censo indicam que em razão do trânsito religioso das pessoas de uma religião para outra, assim como pelo "fraco compromisso" dos mesmos com a religião, é necessário "redescobrir novos caminhos do fazer pastoral".

Apesar do censo ainda não estar finalizado, um ponto revelado pelo mesmo foi o crescimento dos chamados "sem religião". Isso indicaria que as pessoas não estão apenas deixando o catolicismo, mas estão se declarando sem nenhuma religião. E isso, na opinião da Igreja, é algo que precisa ser estudado com atenção, pois é um dado que indica alguma insatisfação com as religiões de uma maneira geral. Este quadro atual somente poderia ser alterado via mudanças na ação da Igreja Católica, a fim de evitar novos índices de queda, finaliza o coordenador ${ }^{4}$.

\section{DIVIDIR PARA SOMAR: A NOVA DIOCESE DE CASTANHAL}

Estudos dos geógrafos Zeni Rosendahl e Roberto Lobato Corrêa, em que analisam a criação de dioceses e prelazias no Brasil no período de 1551 a 1930, revelam que o surgimento das mesmas pode ser dividido em dois recortes temporais: um primeiro, de 1551 a 1854, caracterizado pela dependência da Igreja Católica à Coroa Portuguesa e por uma superficial apropriação e controle de seus territórios ${ }^{5}$; e um segundo período, de 1890 a 1930, contexto da separação entre Igreja e Estado, no qual houve a criação de 68 novas dioceses, distribuídas pelo país, embora concentradas nas regiões Sudeste e Nordeste (ROSENDAHL; CORREA, 2006, p. 1).

A dimensão espacial no processo de evangelização católica é uma importante variável quando se pretende entender a ação católica na Amazônia, tanto no passado como no momento atual.

De fato, não chega a ser um exagero a afirmação de Arthur Cezar Ferreira Reis, de que sem a ajuda das Ordens Missionárias que atuaram na Amazônia nos

\footnotetext{
Até o segundo semestre de 2010, a análise dos dados sobre o censo não tinham sido finalizadas. Doze territórios diocesanos se encontravam dispersos em cerca de 8,5 milhões de $\mathrm{km}^{2}$.
} 
primeiros séculos da colonização "a civilização européia não teria chegado ao mundo amazônico com a rapidez que chegou" (REIS, 1942). As ordens religiosas foram responsáveis tanto pela conquista quanto pelo domínio dos lusitanos sobre espaços na Colônia. Ainda nos primeiros anos de colonização, os Franciscanos da Província de Santo Antonio, que atuavam junto à "bugrada das cercanias de Belém e Una", ajudaram intensamente com seus "catecúmenos", em campanha travada pelos soldados portugueses contra "intrusos brancos" que "eram da família protestante. Hereges, na terminologia da época” (REIS, 1942).

A Igreja Católica teve importante atuação no processo de produção do espaço que mais tarde viria ser chamado de Amazônia. A ação catequética empreendida pelas ordens religiosas, sobretudo pela ordem dos jesuítas, foi de fundamental importância na configuração desse espaço. Basta lembrarmos que, em se tratando do Pará, a maioria das atuais cidades teve origem em aldeamentos e fazendas de missões religiosas (MAUÉS, 1968, p. 26). Os aldeamentos facilitavam o processo de catequização do indígena, ao mesmo tempo em que resguardavam de possíveis invasões as fronteiras de um espaço recém-conquistado.

Assim, a ação missionária foi fundamental no processo de territorialização da Igreja na Amazônia Colonial. Pelos "caminhos líquidos" da Amazônia brasileira, os missionários penetravam e instalavam aldeamentos onde fosse possível (MAUÉS, 1968, p. 25). As práticas de territorialidade levadas a cabo pela Igreja, a exemplo dos aldeamentos, foram formas de materializar no espaço relações de poder e, consequentemente, mecanismo de controle e manutenção de tal poder.

Se na Amazônia Colonial o esforço fundamental da Igreja Católica estava relacionado à ampliação e manutenção de espaços de controle, na atualidade não é diferente. Em tempos de intenso transito religioso e disputa entre instituições religiosas, estabelecer e manter territórios é condição para sobrevivência do grupo.

A constituição do território da Igreja Católica na região do que hoje se concebe como Pará iniciou com a colonização portuguesa e a fundação da Cidade de Santa Maria de Belém do Grão-Pará, em 1616. As Ordens Religiosas foram protagonistas nesse processo, mas a consolidação do território objetivado só se deu quando da organização da Instituição Igreja na Colônia, isto é, com a materialização de objetos geográficos capazes de difundir, além de institucionalizar, relações e normas católicas. Isso se deu com a instituição do recorte territorial chamado diocese.

O desejo de organização de uma diocese nas terras da Amazônia estava ligado, segundo Reis (1964), ao desejo de moralização dos costumes que 
escandalizavam os religiosos, desde que aqui aportaram. Esse desejo só viria se realizar em 1677, com a criação do Bispado do Maranhão, "que abrangia a Amazônia, mas cujos benefícios não abrangiam a colônia paraense". O pedido para ereção de um bispado independente foi feito em 1713. Tal reclamo foi atendido em 1719, com a criação do Bispado do Grão-Pará. Esta Diocese, desmembrada do Bispado do Maranhão, abrangia toda a Amazônia (MAUÉS, 1968; LUSTOSA, 1992) $)^{6}$.

O primeiro desmembramento no bispado do Grão-Pará se deu em 1892, com a criação da Diocese do Amazonas, antes mesmo do Bispado do Grão-Pará ser elevado à condição de arquidiocese, o que se deu no ano de 1906. Desse primeiro desmembramento, outros foram se sucedendo, surgindo, assim, novas dioceses e prelazias. Porém, passaram-se 184 anos entre a criação da primeira diocese - a de Belém, em 1719; e a segunda, a de Santarém, em 19037.

O mais recente desmembramento da Arquidiocese de Belém foi no ano de 2004, com a criação da Diocese de Castanhal. As razões para a criação da mesma foram condensadas no Documento de Pedido de Ereção, enviado a Roma em 2003, assinado pelo arcebispo de Belém à época, D. Vicente Zico. Nas primeiras páginas do documento, ainda na saudação ao falecido Papa João Paulo II, D. Zico apresenta a área que será desmembrada e a justificativa para o desmembramento. O sacerdote informa que está havendo "evasão" de católicos para outras "crenças", e aponta as igrejas de origem "neopentecostais" como as principais causadoras desse fenômeno; além dos neopentecostais, aponta questões como crescimento populacional e dificuldades de evangelização como causas da evasão (ARQUIDIOCESE..., 2003, p. 7). Dentre as inúmeras questões que aparecem como justificativas para a criação de uma nova diocese, o avanço dos pentecostais aparece como questão de número um. O Documento enfatiza que:

\begin{abstract}
A presença de um bispo no interior vai possibilitar mais intensa evangelização que na certa irá sustar o crescimento das seitas protestantes que surgem de maneira assustadora, mercê da ingenuidade e boa fé da pobre gente que não recebe seguro apoio religioso (ARQUIDIOCESE..., 2003, p, 10).
\end{abstract}

6 Quando de sua criação, a diocese de Belém chamava-se Diocese do Grão-Pará e abrangia o Amazonas, Amapá, Roraima, Rondônia, Acre, as Guianas Francesa, Holandesa e Inglesa, a Venezuela, a Colômbia, o Equador, o Peru, a Bolívia, o Mato Grosso, Goiás e Maranhão (cf. LUSTOSA, 1992, p.12).

7 Vejamos a cronologia de criação dessas instituições: Diocese de Belém (1719; Arquidiocese em 1906); Prelazia de Santarém (1903; Diocese em 1979), Diocese de Marabá (1911), Diocese de Bragança (1928); Prelazia do Marajó (1928); Prelazia do Xingu (1934); Diocese de Macapá (1949); Prelazia de Cametá (1952); Prelazia de Óbidos (1957); Diocese de Abaetetuba (1961); Prelazia de Ponta de Pedras (1963; Diocese em 1979); Prelazia de Itaituba (1988) e Diocese de Castanhal (2004). 
O Documento traça um panorama da situação religiosa na área da Arquidiocese de Belém e reconhece a presença de judeus, islâmicos, budistas e "seitas de origem pentecostal". Dos judeus é dito que há na cidade uma "influente comunidade" e a existência de três sinagogas, sendo boa a convivência da Igreja Católica "com a maioria dos judeus", inclusive com a ocorrência de diálogo permanente entre ambos. Acerca dos islâmicos, é dito que "são poucos" em Belém, e que não há "nenhuma mesquita em território da Arquidiocese". Sobre os budistas, o documento diz que seu culto "ainda é de caráter familiar". O mesmo documento informa que há outras religiões de origem oriental e que mesmo estas não sendo muito expressivas no cenário religioso, têm presença sólida no território da Igreja Católica através de seus templos, "especialmente a Igreja Messiânica". O Grupo que merece atenção especial é o evangélico, pois, de acordo com o Documento, causa enorme preocupação, pois sua ação tem graves repercussões (ARQUIDIOCESE ..., 2003, p. 52).

\section{O CÍRIO DA "RAINHA DA AMAZÔNIA"}

A celebração do Círio de Nossa Senhora de Nazaré, em Belém, permitenos pensar na prática algumas questões acima levantadas a partir da instância que a organiza: a Diretoria da Festa $(\mathrm{DF})^{8}$. É bom lembrar que no contexto da celebração do Círio, tanto o modelo de organização de alguns grupos evangélicos, quanto de outras celebrações católica inspiram as práticas desses gestores católicos, no sentido de potencializar as festas. Os católicos, em situação de disputa por mercado, tentam ao mesmo tempo "imitar" um modelo de gerência já colocado em prática por outras celebrações católicas, as quais eles consideram bem sucedidas, a exemplo dos festejos de Nossa Senhora Aparecida, no estado de São Paulo, assim como reproduzem alguns traços da forma de organização e vivência religiosa de algumas instituições evangélicas, a exemplo da forma de capitação de recursos e de uma maior adesão do devoto à Igreja. Com tais práticas, desejam dar novo fôlego ao catolicismo e ao mesmo tempo frear o crescimento dos evangélicos e se colocar, assim, em situação confortável no mercado de bens simbólicos.

\footnotetext{
8 A Diretoria da Festa é a instituição jurídica responsável por organizar todas as celebrações que compõem o Círio de Nazaré. É composta por um conjunto de leigos, todos homens, que assumem suas funções via indicação, e se revezam na mesma num período de dois anos. O presidente da Diretoria é o pároco da Basílica Santuário.
} 
Nos últimos anos, várias ações foram tomadas no sentido de potencializar a celebração do Círio ${ }^{9}$, dentre estas destaco três: O Projeto Patrocinador Oficial do Círio de Nazaré (PPOCN), a criação da Associação dos Devotos de Nossa Senhora de Nazaré (ADENAZA) e o desejo de registro de uma "marca Círio".

Os organizadores do Círio têm se orientado, desde a última década, principalmente, para gerenciar a celebração de uma forma mais "empresarial". Palestras com especialistas em marketing católico são ministradas para os membros da Diretoria da Festa, com o intuito de prepará-los para se "comportar" de forma mais eficiente no mercado de bens simbólicos. Como parte desse propósito, Belém sediou, em maio de 2009, o $14^{\circ}$ Encontro de Marketing Católico, promovido pelo Instituto Brasileiro de Marketing Católico (BMC).

Formas “modernas" de captação de recursos que visam manter a celebração em situação financeira confortável, e que ao mesmo tempo não permitam que essa captação de recursos seja feita por outras religiões, fazem parte desse processo de "gerência empresarial". A preocupação em captar recursos está relacionada à vontade de organizar a festividade do Círio, para que ela se torne um evento cada vez mais eficiente, em todos os sentidos.

\section{O Projeto Patrocinador Oficial do Círio de Nazaré: o negócio sagrado}

Quando do lançamento do projeto em 2003 havia apenas uma preocupação empresarial, dada a necessidade de arrecadar recursos. Nós não tínhamos dinheiro pra fazer o Círio. O Círio não acontece por um milagre de Deus, alguém tem que providenciar e pagar a corda, as flores que ornamentam todas as procissões... Tem que mandar fazer e pagar o manto que veste Nossa Senhora... Então nós tínhamos uma visão muito empresarial: nós precisávamos de dinheiro, a Basílica não tinha dinheiro para bancar o Círio (Diretoria da Festa, agosto, 2008).

\footnotetext{
Alves (1980) percebeu um processo de mudança de gerência na organização do Círio desde a década de 1970, mas foi a partir da primeira década do século XXI que a gerência se especializou de fato. Eis algumas das ações nos anos mais recentes: adoção do Projeto Patrocinador Oficial do Círio de Nazaré em 2003; Registro do Círio como Patrimônio Imaterial do Brasil pelo instituto do Patrimônio Histórico e Artístico Nacional (IPHAN) no ano de 2004; transformação da Basílica de Nazaré em Santuário, em maio de 2006; reforma da Praça Santuário, em 2008; Lançamento do Portal da Basílica Santuário de Nazaré na Internet, em 2008; construção da Casa de Plácido no ano 2008\2009, publicação do "Livro do Círio", em 2009; climatização do Santuário Basílica de Nazaré, em 2006; projeto de construção do Centro Social e Casa de Oração D. Orani João Tempesta - campanha lançada em abril de 2009; transformação do Arraial em um "Complexo Artístico Cultural”, a partir de 2010, com retirada dos bares e restaurantes do interior do Arraial e, consequente eliminação da venda de bebidas alcoólicas, em julho de 2010; apresentação à UNESCO da candidatura do Círio como Patrimônio Cultural da Humanidade e a criação do projeto Apoiador Oficial do Círio, em 2011.
} 
Grosso modo, esse projeto consiste em um contrato entre a Diretoria da Festa e empresas públicas e privadas de nível local e nacional. Tal contrato prevê parceria entre ambas. Depois de chamada pública para que as empresas interessadas se apresentem, respeitando as devidas exigências da Diretoria da Festa, é assinado um acordo entre as partes. Cumpridas as exigências necessárias, a Diretoria da Festa dispensa às empresas a possibilidade de uso comercial de elementos ligados à celebração no mercado secular, como fotos da imagem da santa, fitas, fotos da corda do círio, das procissões, ou de qualquer outro elemento de forte associação com a celebração ${ }^{10}$. Em contrapartida, as empresas dispensam à Diretoria da Festa o pagamento da cota estipulada em contrato, em espécie ou em serviços. Dessa forma, ambas "saem ganhando". Segundo membros da Diretoria da Festa, a Diretoria ganha porque tem um rendimento financeiro mais "folgado" para fazer o Círio; e as empresas lucram porque se aproveitam do grande potencial de vendas presente na celebração e promovem seus produtos. A partir da adoção desse projeto, qualquer empresa que utilize elementos ligados à celebração sem o consentimento da Diretoria da Festa poderá ser acionada judicialmente.

A redação do projeto Patrocinador Oficial do Círio de Nazaré foi elaborada pela própria Diretoria Jurídica da Diretoria da Festa, tendo como objetivo, segundo seus proponentes, disponibilizar ao Círio um maior conforto financeiro, evitando, assim, que as verbas doadas pelo poder público estadual e municipal para realização do mesmo sejam "desviadas" para as Obras Sociais da Paróquia de Nazaré (OSPAN) ${ }^{11}$, instituição que não tem outro rendimento senão aquele direcionado ao Círio. Assim, através do PPOCN a Diretoria garante, além da realização da celebração do Círio, assistência às Obras Sociais da Paróquia de Nazaré, ação que funciona o ano todo com obras de caridade. A ideia do patrocínio oficial pode ser considerada como muito exitosa. Desde o seu lançamento em 2003 tem mantido o número de patrocinadores entre 11 e 18, e as empresas patrocinadoras têm variado pouco ${ }^{12}$.

Pode-se dizer que a ideia de "gerencia empresarial" ganhou contornos mais definidos na década de 1990, quando o publicitário Oswaldo Mendes Filho assumiu a Diretoria de Marketing da Diretoria da Festa, que naquele tempo

10 É bom dizer que no caso da imagem da santa, somente são utilizadas fotos da imagem peregrina. Imagens da santa conhecida como "original” não são utilizadas.

11 A OSPAN envolve sete comunidades de assistência social que dão assistência a crianças e adultos: Comunidade São Braz, Comunidade Santo Antonio Maria Zaccaria, Comunidade Sagrada Família, Comunidade São José, Comunidade Padre Afonso, Creche Sorena e Comunidade Nossa Senhora das Graças.

12 O projeto iniciou em 2003, com 11 empresas; em 2004, foram 14; em 2005, foram 13; em 2006, 14; em 2007, 17; em 2008 18; e nos anos de 2009 e 2010, foram 17. 
não tinha ainda esse nome, mas algo como "relações públicas e propaganda". O orçamento do Círio era o principal problema da Diretoria nesse tempo. O "custo Círio" era muito alto e a forma de captação de recursos se restringia às doações que eram feitas através do "Livro de Ouro" e pelo poder público local. As doações eram feitas sem preocupações com contrapartida ou "produto Círio". Tal prática "sangrava os cofres" da Igreja, na opinião da Diretoria. A partir disso, começou a se pensar num trabalho de "profissionalização", com o intuito de mostrar aos leigos e ao clero que o Círio é um "grande produto", a exemplo de outras celebrações, como "Nova Jerusalém, em Pernambuco, que é bancada pela iniciativa pública", comenta um ex-coordenador da festa.

Com o PPOCN não mais se pede; se oferece um produto chamado Círio e em contrapartida aos investimentos financeiros que essas empresas fazem, a Diretoria oferece uma série de produtos e serviços relativos ao Círio. Isso fez com que houvesse uma "evolução no Círio" tanto no seu fazer como nos serviços sociais que a Basílica Santuário realiza e alguns outros serviços, como climatização da Basílica e reformas de capelas da paróquia (Diretoria da Festa, agosto de 2008). Empresas sérias, grandes, conhecidas, muitas delas nacionalmente e que nos dá hoje... Na verdade, eu diria que é o grande sustentáculo para a realização do Círio. É claro que o Círio sempre existirá, mas eu não sei em que condições existiria hoje se não fosse esse projeto, se não fosse esse dinheiro que, nada, nada, representa hoje mais de um milhão de reais. O projeto vingou, é um projeto de sucesso, nós temos, neste ano de 2008, 18 patrocinadores não só locais, mas grandes empresas nacionais bancando o Círio (Diretoria da Festa, agosto de 2008).

Mas não apenas em negócios trabalham estes homens. As razões para toda essa movimentação da Igreja rumo ao mercado têm como natureza a questão da evangelização. Em entrevista com membros da Diretoria da Festa, é ressaltada a capacidade desta em lidar com os "negócios sagrados" no Círio e com a missão evangelizadora, pois a mesma teria:

Uma veia empresarial, que é necessária, dada a necessidade de angariar recursos para o Círio e para as OSPAN, porém, sem esquecer que nós somos Igreja; e sendo Igreja, nosso principal objetivo é evangelizar (Diretoria da Festa, agosto de 2008).

Evangelizar é a principal função da igreja. Em situação de pluralismo religioso, essa tarefa se potencializa. Sem um eficaz trabalho de evangelização, as instituições religiosas correm o risco de enfraquecer-se perante as outras. Nesse sentido, o esforço de evangelização é também uma estratégia significativa no sentido de sobrevivência num universo-mercado em que atuam várias formas 
religiosas, num contexto em que os fiéis se encontram livres para transitar simultaneamente por várias instituições religiosas, sem se filiar a nenhuma ou para optar por aquela que mais condições favoráveis lhes oferecem, aquilo que Guerra (2006) chama de força da demanda de consumidores.

Isso implica que as ações da Diretoria em relação ao Círio, mesmo quando dizem respeito ao mercado, tenham sempre como pano de fundo a questão da evangelização, pois no atual contexto, esta não se encontra desligada do mercado. De fato, segundo o arcebispo de Belém à época, D. Orani João Tempesta, que ficou à frente do bispado paraense no período de 2004 a 2009, a função da Diretoria é evangelizar o ano todo, e não apenas no Círio. No intuito de colocar essa intenção em prática há ideias do sentido de fazer o "Círio fora de época". Esse desejo surgiu ainda no bispado de D. Vicente Zico à frente da Arquidiocese, no período de 1990 a 2004, e foi reforçada por seu sucessor, D. Orani João Tempesta.

Visando que o Círio seja uma realidade durante o ano todo, e não apenas em outubro, há projetos no sentido de estender as peregrinações que antecedem o Círio para um tempo maior. Tal alongamento do Círio não significa, no entendimento de seus organizadores, uma forma de banalização do mesmo, pois tudo "seria feito com muita disciplina e fé". O objetivo é "evangelizar". O uso do Livro das Peregrinações ${ }^{13}$ é necessário, na visão da Diretoria. A razão para tanta ênfase na evangelização é explicada:

A Igreja não estava preparada [...] Com os meios [...] principalmente o que usa muito o evangélico com os meios do marketing pra divulgar, pra propagar essa fé. Então você vê o exemplo mais latente disso que eu estou falando é o Edir Macedo, que criou uma igreja universal. Universal no sentido de estar no mundo todo. Mas, qual é o grande vetor dele? Não é o templo não. O grande vetor dele é a rede de rádio e televisão - é nisso que ele sabe trabalhar, e sabe muito bem. Daí, se nós formos analisar em nível regional, você vê a preocupação que vem desde D. Carlos Verzeletti, que hoje é bispo de Castanhal, quando implementou a Fundação Nazaré de Comunicação, com a televisão o rádio e o jornal, justamente nessa visão que ele tem. D. Carlos é uma pessoa que tem uma visão de marketing religioso; ele sabe como levar a palavra de Deus aonde precisa ser levada e ele faz uso disso muito bem [...]. Esse processo é visto como uma "evolução natural" da Igreja, que viu que não poderia ficar limitada, restrita ao templo, ao santuário, pra essa divulgação que precisava usar os meios modernos de comunicação, o jornal, a TV, o rádio, sem esquecer a igreja, a capela, a basílica, o Círio. A gente sentia um afastamento do fiel católico da sua igreja, até pelo desconforto que ela propiciava: bancos desconfortáveis, calor insuportável. Foi uma outra preocupação. Hoje é difícil você encontrar

13 Cartilha publicada pela Fundação Nazaré, que orienta os leigos na feitura das peregrinações.

Novos Cadernos NAEA •v. 15 n. $2 \cdot$ p. 261-278 • dez. 2012 
uma igreja que não seja climatizada, que não tenha banco um pouco melhor para receber o fiel. Isso foi uma maneira de se trazer de volta essa turma que andava um pouco afastada (Diretoria da Festa, agosto de 2008).

No círio do ano de 2011, a Diretoria ampliou as formas de capitação de recursos. Implantou o Projeto Apoiador Oficial do Círio de Nazaré, que é um modelo semelhante ao PPOCN, um pouco mais modesto em seus valores. A justificativa para a implantação do mesmo, apoia-se na crescente demanda de pessoas que desejam "apoiar" o Círio devido a sua "infraestrutura" e "potencial de venda" ${ }^{14}$.

\section{Associação dos Devotos de Nossa Senhora de Nazaré: ampliando o campo de devoção}

A Associação dos Devotos de Nossa Senhora de Nazaré (ADENAZA) é uma das formas recentes que a DF colocou em prática, visando captar recursos para o Círio. Além de apoio financeiro, o projeto estende a rede de devotos da santa para todo o Brasil e para outros países, visto que todo o processo de filiação ao mesmo pode ser feito também pela internet ${ }^{15}$.

A ADENAZA é uma associação da Basílica Santuário de Nazaré, que reúne devotos de Nossa Senhora, "que de maneira dinâmica e atual procura difundir essa devoção por meio de celebrações e programas de televisão". Um dos objetivos do projeto é angariar recursos que possibilitem que o culto a Nossa Senhora de Nazaré possa se ampliar por meio virtual, para "todas as localidades do Brasil”. Além disso, visa contribuir financeiramente para a manutenção da própria Basílica Santuário e suas instituições de caridade. O projeto foi pensado entre os anos de 2004 e 2005, mas foi implementado somente no ano de 2007, porque precisava ser aperfeiçoado.

Esse modelo de "gestão burocrática" caracterizado pela presença dos projetos acima citados, não se restringe à adoção dos mesmos, é, inclusive, anterior a estes. Alves (1980, p. 78-80), que usa o termo "tecnocrata" para indicar tal fenômeno, comenta acerca dos esforços da DF, em meados da década de 1970, para "racionalizar" a celebração, especialmente partir do ano de 1974, quando assumiu a Diretoria um empresário e professor universitário que desejava

14 Esse projeto de apoio é muito semelhante ao de patrocínio, com algumas vantagens para este último. Os valores das cotas de ambos os projetos traduzem um pouco da relação de prestígio entre ambos. Enquanto a cota de investimento do apoiador será de R \$10.000,00 (dez mil reais), a de patrocinador será de $\mathrm{R} \$ 70.000,00$ (setenta mil reais), para o Círio de 2011.

15 As informações aqui relatadas foram retiradas do folheto divulgação do projeto, distribuído na Basílica Santuário de Nossa Senhora de Nazaré, em novembro de 2008. 
dar "nova ordem ao Círio". É nesse contexto de "nova ordem" que o Círio é entendido como uma "tradicional festividade que tem a um só tempo um caráter: religioso, recreativo, turístico e educativo”. É também em 1974 que é realizada a primeira grande pesquisa sobre o Círio, em parceria com a Universidade Federal do Pará, tendo como coordenador o padre e professor Savino Mombelli. Essa pesquisa foi condensada no livro Valores Religiosos do Círio de Nazaré, e tinha como propósito entender o Círio a partir dos pontos de vista "religioso, ético e antropológico". Objetivava também traçar estratégias para melhor gerenciálo. Após esse estudo, várias medidas foram tomadas no sentido de melhor "gerenciar" a celebração ${ }^{16}$.

Ao longo das quase três décadas que separam a pesquisa de Alves para a implantação do PPOCN, o Círio passou por um grande processo de mudança que, de forma geral, configurou-se a partir da década de 1980. Foi nessa década, por exemplo, que se iniciou a dispersão da celebração para além de seu lugar de origem, o tradicional Largo de Nazaré, para outros lugares de Belém e para municípios da Região Metropolitana, devido às novas celebrações criadas, que dessa data em diante não vão deixar de crescer $^{17}$.

E de onde surgiu toda essa ideia de gerência empresarial? Da própria necessidade dos diretores da festa de acompanhar no plano gerencial o crescimento que a celebração já vinha experimentando em termos de participação de pessoas e de notoriedade regional e nacional, assim como a introdução cada vez maior do Círio no contexto daquilo que entendemos como manifestação cultural, o que, se por um lado o colocava num lugar interessante em termos de divulgação, por outro, era motivo de preocupação para a Igreja, que temia o seu esvaziamento, do ponto de vista religioso. A partir desse contexto, os diretores da festa idealizaram alguns dos projetos mais significativos no atual Círio ${ }^{18}$.

16 Dentre estas medidas, podemos citar a implantação de um sistema de comunicação autônomo, que permite um comando único no momento das procissões - antes, usava-se o sistema de frequência da Polícia Militar do Estado; a criação de Guarda de Nossa Senhora de Nazaré, responsável pela disciplina na corda do Círio e no espaço do Arraial; a retirada de bares e de alguns brinquedos do Arraial considerados não educativos; o término dos leilões de terrenos, que aconteciam todos os anos para compradores interessados em adquiri-los temporariamente por conta do Arraial; uso do espaço do arraial como lugar de divulgação da ideia de “desenvolvimento", sobretudo dos órgãos preocupados com o desenvolvimento da Amazônia, tanto em nível federal como estadual.

17 É a partir da década de 1980 que surgem sete das onze procissões que compõem o Círio atualmente. Para maiores detalhes ver Pantoja (2006).

18 A introdução daquilo que aqui chamo de lógica mercadológica, não deixa de estar relacionada ao perfil dos dirigentes da celebração do Círio. Os diretores são homens oriundos do conhecimento acadêmico, com formações as mais variadas; eles não deixam de lançar mão desse conhecimento quando precisam agir enquanto diretores do Círio.

Novos Cadernos NAEA • v. 15 n. 2 • p. 261-278 • dez. 2012 
As ideias da Diretoria passam a ganhar forma depois da visita do grupo de diretores aos Santuários de Aparecida, no estado de São Paulo e Nova Jerusalém, no estado de Pernambuco. Assim, os arranjos feitos pela Diretoria na gerência do Círio são articulados, tendo como referência o seu crescimento enquanto celebração cultural e, ao mesmo tempo, religiosa, visto que na opinião dos diretores, esta seria capaz de frear a evasão de católicos para o universo evangélico. Daí que as ações da Diretoria tanto se referem ao universo católico, aqui exemplificado pela "imitação" de celebrações católicas, quanto por práticas dos evangélicos, especialmente aquelas ligadas ao item captação de recursos financeiros. Isso caracterizaria, para além da prática da imitação, que levaria ao fenômeno da padronização dos produtos religiosos, como aponta Berger (1985), a noção mais ampla de mímesis apontada por Girard (2008), como aquela característica humana necessária à própria noção de aprendizado.

Esse processo de burocratização impõe uma série de mudanças para as festa de santo como um todo. Impõe também desafios aos seus gestores, a exemplo da necessidade de lidar com questões novas que acompanham a burocracia. A noção de direito de propriedade aplicada aos bens simbólicos é um desses desafios.

\section{O direito de propriedade sobre os bens simbólicos: a marca Círio}

Antes mesmo da adoção do PPOCN, a Diretoria da Festa já sentia a necessidade de resguardar para si os direitos de uso de elementos ligados à celebração, muitos amplamente utilizados pelo mercado. Com esse intuito, deu entrada junto ao Instituto Nacional de Propriedade Intelectual (INPI) com um pedido de registro da marca Círio de Nazaré ${ }^{19}$. O processo vem se arrastando desde 2000, quando foi solicitado, e até então sua condição é de "marca depositada". Como marca depositada, segundo um dos diretores, a DF já tem certas regalias, no sentido de fazer valer algum direito sobre esse bem.

A gente não quer impedir ninguém de usar a marca Círio, mas a gente quer disciplinar e quer fazer reverter isso em benesses, em benefícios para a comunidade católica. Antigamente, quando a gente lançava o cartaz oficial do Círio, normalmente à noite, no dia seguinte a cidade tava cheia de ambulantes vendendo a camisa com o cartaz estampado. Aquilo é uma propriedade da Diretoria da Festa. Aquela foto que ilustra o cartaz foi doada por um fotografo para as Obras Sociais da Paróquia de Nazaré e a criação daquele cartaz foi doada por uma agência [...]. Então

19 Mais de dez anos passados, não se tem maiores detalhes sobre esse pedido. A Diretoria da Festa evita falar sobre o assunto, e no portal do Círio na internet não há referência ao pedido. 
era injusto que alguém se apoderasse daquilo sem pagar absolutamente nada e fizesse o uso que bem entendesse. E de repente a gente viu um grande anunciante fazendo uso do cartaz, sem pagar nenhum royalty [...]. Quando é natural que se você emprestar a sua voz, a sua imagem, a sua foto, você recebe por isso (Diretoria da Festa, agosto de 2008).

Já alicerçada em algumas noções relativas à propriedade intelectual, a Diretoria contatou os fornecedores de transfer em todo Brasil e comprou deles a produção relativa à imagem da Santa. Após isso, um comunicado foi feito à praça, alertando aqueles que trabalham com estamparia de camisas, bolsas, chapéus, entre outros.

Olha, ninguém vai impedir ninguém de trabalhar e vender o seu produto não é esse nosso objetivo. Nós apenas queremos que você compre da gente. Só nós somos autorizados a vender isso. Então, disciplinou. Hoje, todo mundo que vende a camisa continua vendendo, e vendendo muito, compra da gente. Quer dizer, é uma questão de disciplina, porque você via coisas absurdas [...].E nosso objetivo não era o pequeno vendedor ou ambulante, não. Mas as grandes empresas, poderosas - empresas fazendo uso da imagem que nos pertencia. Isso é uma apropriação indevida, juridicamente fácil de defender (Diretoria da Festa, agosto de 2008).

É em um momento considerado delicado para a Igreja Católica que essas práticas ganham relevo, e podem ser analisadas como formas de a mesma se (re) colocar no mercado de bens simbólicos. Para tanto, a mesma divide o território, faz censo para conhecer os "consumidores do sagrado", no sentido de atendêlos com um produto que satisfaça suas expectativas e potencializa o seu produto mais bem cotado no mercado: o Círio.

A Diretoria da Festa, uma espécie de microcosmo da Igreja Católica, põe em prática as ações que visam melhorar tal produto. Para tanto, cuida do preparo técnico dos gestores do Círio, e tenta, via vários projetos, torná-lo cada vez mais potente, por meio da captação de recursos financeiros cada vez mais vultosos.

É na interface de uma instituição religiosa que ao mesmo tempo funciona como empresa secular, que a Diretoria da Festa vem a cada ano se colocando no mercado. Como empresa secular, a instituição precisa estar de olho no mercado o tempo todo, pois cada ação precisa ser cuidadosamente planejada quando se lida com o comércio de um "produto" que é também um bem simbólico.

Como instituição religiosa, a Diretoria precisa zelar pelo caráter religioso e evangelizador da maior festa católica dos paraenses, estando atenta para a natureza religiosa, disciplina e controle sobre os mecanismos que fazem do Círio não somente uma grande festa para os paraenses, mas também uma grande celebração religiosa capaz de demonstrar a força da Igreja Católica nesta região. 


\section{CONSIDERAÇÕES FINAIS}

Nem todas as práticas recentemente levadas a cabo pelas gerências das festas de santo, a exemplo do Círio, são exclusivamente em razão do crescimento dos evangélicos. Elas fazem parte do processo de movimentação da Igreja rumo à manutenção de um lugar que ela deseja exclusivo, mas que no momento se apresenta de maneira diversificada, sendo os evangélicos o elemento que ameaça a sua condição de agência exclusiva nesse mercado.

A própria igreja católica tem acreditado que o crescimento dos evangélicos é sintoma ou efeito "dos tempos"; tempos de mudança cultural, de pluralismo religioso, de intensa urbanização, de individualismos, de globalização dos meios de comunicação de massa, enfim, daquilo que ela tem chamado de modernidade. Entender o que a igreja entende por modernidade e como tem se movimentado nesse contexto é uma tarefa importante neste sentido.

\section{REFERÊNCIAS}

ALVES, I. O carnaval devoto. Um estudo sobre a festa de Nazaré em Belém. Petrópolis: Vozes, 1980.

ARQUIDIOCESE DE BELÉM. Pedido de ereção de nova diocese. Belém, 2003.

BARROS, L.; PANTOJA, V. Dossiê das Festividades do Glorioso São Sebastião na mesorregião Marajó. Belém: IPHAN, 2010.128p. Mimeografado. GUERRA, L. Mercado religioso no Brasil: competição, demanda e dinâmica da espera da religião. João Pessoa: Idéia, 2003.

Mercado religioso na Paraíba: a competição e o aumento da racionalização das atividades das organizações religiosas. Religião e Sociedade, v. 26, n. 2, p, 155-185, 2006.

JACOB, C. R. et al. Religião e sociedade em capitais brasileira. Rio de Janeiro: PUC; São Paulo: Loyola; Brasília: CNBB, 2006.

LUSTOSA, D. A. de A. Dom Macedo Costa - Bispo do Pará. Belém: Secult, 1992. (Série Lendo o Pará, 13).

MAUÉS, R. H. Ação das ordens e congregações religiosas na Amazônia: Belém: [s.n.], 1968. 
MAUÉS, R. H. Padres, pajés, santos e festas: catolicismo popular e controle eclesiástico. Belém: Cejup, 1995.

MOMBELLI, S. Valores religiosos do Círio de Nazaré. Belém: UFPA, 1976. PANTOJA, V. Negócios Sagrados: reciprocidade e mercado no Círio de Nazaré Belém-PA. 2006. 135f. Dissertação (Mestrado em Antropologia Social) Programa de Pós-Graduação em Ciências Sociais, Universidade Federal do Pará, Belém, 2006,

As festas de Santo no Marajó. In: LIMA, M. D.; PANTOJA, V. Marajó: Cultura e Paisagem. Belém: 2a SR/IPHAN, 2008.

Santos e Espírito Santo, ou Católicos e Evangélicos na Amazônia Marajoara. 2011. 208f. Tese (Doutorado em Antropologia Social) - Programa de Pós-Graduação em Ciências Sociais, Universidade Federal do Pará, Belém, 2011.

REIS, A. C. F. A formação espiritual da Amazônia. Rio de Janeiro: SPVEA, 1964.

A conquista espiritual da Amazônia. São Paulo: Escolas Profissionais Salesianas, 1942. 